IOSR Journal of Pharmacy

ISSN: 2250-3013, www.iosrphr.org

\title{
Evaluation of hepatoprotective activity of abelmoschus moschatus seed in paracetamol induced hepatotoxicity on rat
}

\author{
Abhishek Kumar singh ${ }^{1}$, sanjiv singh ${ }^{2}$, h.s. Chandel $^{3}$ \\ ${ }^{I}$ Department of Pharmacology "Truba Institute of Pharmacy", Bhopal (M.P $)^{1}$ \\ ${ }^{2}$ Department of Pharmacology "Truba Institute of Pharmacy", Bhopal (M.P $)^{2}$ \\ ${ }^{3}$ Department of Medicinal Chemistry "Truba Institute of Pharmacy", Bhopal (M.P $)^{3}$
}

\begin{abstract}
Paracetamol (PCM) is widely used as analgesic and antipyretic drug, but at high dose it leads to undesirable side effects, such as hepatotoxicity. This study gives the information about hepatoprotective activity of abelmoschus moschatus seed extract against paracetamol and ethanol induced hepatotoxicity. Paracetamol induce hepatotoxicity was evaluated by an increase $(P<0.05)$ in serum AST, ALT, ALP activity and bilirubin level Paracetamol hepatotoxicity was manifested by an increase $(P<0.05)$ lipid peroxidation, depletion of reduced glutathione (GSH) and catalase activity in liver tissue. Administration of etanolic as well as aqueous plants extract [300 $\mathrm{mg} / \mathrm{kg}$ body weight of rat] protects the paracetamol induced lipid peroxidation, restored altered serum marker enzymes and antioxidant level towards normal. The results indicate hepatoprotective activity of all studied plants extract against paracetamol induced toxicity. Ethanolic extract was found more significant than the aqueous extract.
\end{abstract}

Keywords: ethanol, hepatoprotective, paracetamol, silymerine, whister rats

\section{INTRODUCTION}

The liver plays a central role in transforming and clearing chemicals and is susceptible to the toxicity from these agents. Certain medicinal agents, when taken in overdoses and sometimes even when introduced within therapeutic ranges, may injure the organ. Other chemical agents, such as those used in laboratories and industries, natural chemicals (e.g., microcystins) and herbal remedies can also induce hepatotoxicity. Chemicals that cause liver injury are called hepatotoxins. [Friedman, et al, 2003]

Paracetamol is widely used as antipyretic and analgesic drugs, causes hepatotoxicity if taken in the excess amount of dose. The mechanism of hepatotoxicity is firstly cause the necrosis of Centilobular hepatocytes and followed by lipid per oxidative degradation of glutathione and produces cell necrosis in liver due to the formation of intermediate oxidative product of paracetamol (N-acetyl-P-benzoquinoneimine).(Kapur V. et al, 1994)

The abelmoschus moschatus seed belong to family Malvaceae. It contains sitosterol b. total phenol, flavonoids which are responsible for antioxidant, antimicrobial and free radical scavenging activity. [[Rastogi, Mehrotra, 1991, Mir Z Gul1, et al, 2011,]

It also shows protective mechanism in Respiratory troubles and asthma Antispasmodic Itch [I.M. Liu, et al, 2010]

Drugs and Chemicals:

\section{MATERIAL AND METHODS}

Paracetamol was purchased from the local market of Bhopal in the tablet dose form by the PARACIP500 brand name product of "CIPLA" on 28/01/2012. Silymarin was purchased from in the capsule dose form LIMARIN ${ }^{\circ} 70$ by the brand name product of Serum Institute of India Ltd on 28/01/2012. Other chemicals Petroleum ether, Ethanol are also used.

Instruments used- Weighing machine, Grinder, Soxhlet, Analytical balance, and Water bath.

Plant Material:

$1 \mathrm{~kg}$ of dried seed of Abelmoschus moschatus was collected from the local market of Bhopal on 28/01/2012. Abelmoschus moschatus seed was authenticated by the Head of Department of botany Dr.zia Ul Hasan Professor of Safia College of Science Bhopal. Plant authentication no. is 346/Bot/Safia/2012 on the date$14 / 02 / 2012$. Seed was grind by the Grinder mixture and extract was collected from that powder with the help of Soxhlet apparatus. 
Animals:

Male Wistar rats weighing $200 \pm 20 \mathrm{~g}$ were used for this study. The animals were kept in polypropylene cages and maintained at $25 \pm 5^{\circ} \mathrm{C}$ and $60 \pm 5 \%$ humidity under $12 \mathrm{~h} \mathrm{light/dark} \mathrm{cycle.} \mathrm{The} \mathrm{animals} \mathrm{were} \mathrm{allowed}$ free access standard pellet diet and water. The animal experiment was performed according to the guidelines laid by Institutional Animal Ethical Committee (IAEC).

Experimental protocol:

Animals were divided into five groups of six rats each and treated orally as below for 14 days.

Group-1: Normal control, given water daily for 14 days (o.d).

Group-2: Standard, Paracetamol $(500 \mathrm{mg} / \mathrm{kg}$ body weight $)+30 \%$ ethanol + Silymarin $(25 \mathrm{mg} / \mathrm{kg}$ body weight $)$ p.o. for 14 days (o.d).

Group-3: Paracetamol control, given water daily for 14 days followed by single dose of paracetamol $(500 \mathrm{mg} / \mathrm{kg}$ body weight $)+30 \%$ ethanol p.o. for 14 days (o.d)

Group-4: Ethenolic Extract $(300 \mathrm{mg} / \mathrm{kg}$ body weight $)+$ Paracetamol $(500 \mathrm{mg} / \mathrm{kg}$ body weight $)+30 \%$ ethanol p.o. dose for 14 day (o.d).

Group-5: Aquous Extract (300mg/kg body weight) + Paracetamol (500mg/kg body weight) $+30 \%$ ethanol p.o. dose for 14 days (o.d).

Animals were sacrificed under light chloroform anesthesia 24-h after the last dose. Blood was collected by retro orbital plexus puncture.

Biochemical Assays:

Serum marker enzymes of liver function: Serum was separated by cooling centrifugation at $3000 \mathrm{rpm}$ at $4{ }^{\circ} \mathrm{C}$ for $10 \mathrm{~min}$ and used for measurement of various biochemical markers such as SGOT, SGPT, (AST and ALT) activities, alkaline phosphatase (ALP) activity, and total bilirubin using commercially available kits.

Statistical analysis:

The values were expressed as mean \pm SD. Statistical analysis and comparison between the groups was performed by one way analysis of variance (ANOVA)

Difference between unexposed and exposed (with or without treatment) with a $p$-value <

0.05 was considered significant.

\section{Result}

Table1. Pharmacognostical screening of powder

\begin{tabular}{|l|l|l|}
\hline S. no. & Component & Result \\
\hline 1. & Moisture content & $11.14 \%$ \\
\hline 2. & Ash value & $15 \%$ \\
\hline
\end{tabular}

Table2. Pharmacognostical screening of extract

\begin{tabular}{|c|c|c|c|}
\hline \multirow[t]{2}{*}{ S. no. } & \multirow[t]{2}{*}{ Test } & \multicolumn{2}{|c|}{ Observation } \\
\hline & & Alcoholic & Aquous \\
\hline 1. & Flavonoid & $+\mathrm{ve}$ & $+\mathrm{ve}$ \\
\hline 2. & Totalphenolic compound & $+\mathrm{ve}$ & $+\mathrm{ve}$ \\
\hline 3. & Alkaloids & -ve & _ve \\
\hline 4. & Saponines & -ve & - ve \\
\hline 5. & Glycosides & _ve & -ve \\
\hline 6. & Tannins & -ve & -ve \\
\hline 7. & Resins & $+\mathrm{ve}$ & _ve \\
\hline 8. & Nitrogenous compound & $+\mathrm{ve}$ & $+\mathrm{ve}$ \\
\hline
\end{tabular}


Evaluation of hepatoprotective activity of abelmoschus moschatus seed in paracetamol induced...

Table 3. Acute oral toxicity test

\begin{tabular}{|l|l|l|l|}
\hline S. no. & Dose in ml & No. of animals & Observation \\
\hline 1. & $300 \mathrm{mg} / \mathrm{kg}$ & 3 & All animal survived \\
\hline 2. & $600 \mathrm{mg} / \mathrm{kg}$ & 3 & All animal survived \\
\hline 3. & $1200 \mathrm{mg} / \mathrm{kg}$ & 3 & All animal survived \\
\hline 4. & $1600 \mathrm{mg} / \mathrm{kg}$ & 3 & All animal survived \\
\hline 5. & $2000 \mathrm{mg} / \mathrm{kg}$ & 3 & All animal survived \\
\hline
\end{tabular}

Table 4. Evaluation of Antioxidant Activity of Abelmoschus moschatus seed extract against DPPH scavenging.

\begin{tabular}{|l|l|l|l|}
\hline \multirow{2}{*}{ S. no. } & \multirow{2}{*}{$\begin{array}{l}\text { Concentration } \\
(\mu \mathrm{g} / \mathrm{ml})\end{array}$} & \multicolumn{2}{c|}{ \% inhibition } \\
\cline { 3 - 4 } & 100 & 32.32 & Alcoholic \\
\hline 1 & 120 & 29.00 & 55.23 \\
\hline 2 & 140 & 26.22 & 52.86 \\
\hline 3 & 160 & 23.43 & 50.41 \\
\hline 4 & 180 & 21.43 & 47.00 \\
\hline 5 & 200 & 19.10 & 43.10 \\
\hline 6 & & & 41.11 \\
\hline
\end{tabular}

Table 5. Evaluation of effect of Abelmoschus moschatus on serum SGOT, SGPT, ALP, T.B in paracetamol + ethanol induced hepatotoxicity.

\begin{tabular}{|c|c|c|c|c|c|}
\hline \multirow[t]{2}{*}{ S. no. } & \multirow[t]{2}{*}{ Group } & \multicolumn{4}{|c|}{ BLOOD SERUM BIOCHEMICAL DATA(MEAN \pm SEM ) } \\
\hline & & SGOT(IU/L) & SGPT(IU/L) & ALP(IU/L) & T.B(mg/dl) \\
\hline 1. & Control & $67.5 \pm 3.35$ & $76.66 \pm 2.47$ & $26.66 \pm 3.073$ & $1.41 \pm 0.305$ \\
\hline 2. & Standard & $75.83 \pm 2.386$ & $85.83 \pm 4.362$ & $35.83 \pm 2.713$ & $\begin{array}{l}2.0 \pm 0.18 \\
2\end{array}$ \\
\hline 3. & -ve control & $\begin{array}{l}109.16 \pm 2.713 \\
a^{* * *}, b^{* * *}\end{array}$ & $\begin{array}{l}202.5 \pm 4.787 \\
\mathrm{a} * * *, \mathrm{~b} * * *\end{array}$ & $\begin{array}{l}97.5 \pm 5.881 \\
a^{* * *}, b^{* * *}\end{array}$ & $\begin{array}{l}6.0 \pm 0.8062 \\
a^{* * *}, b^{* * *}\end{array}$ \\
\hline 4. & Eth-extract & $\begin{array}{l}90 \pm 2.887 \\
\mathrm{a}^{* * *}, \mathrm{~b} *, \mathrm{c} * *\end{array}$ & $\begin{array}{l}104.16 \pm 2.386 \\
a^{* * *}, b^{*}, c * * *\end{array}$ & $\begin{array}{l}56.66 \pm 6.54 \\
a^{* *}, b^{*}, c^{*} * *\end{array}$ & $\begin{array}{l}3.08 \pm 0.327 \\
\text { c*** }\end{array}$ \\
\hline 5. & Aq-extract & $\begin{array}{l}100 \pm 2.887 \\
a^{* * *}, b^{* * *}\end{array}$ & $\begin{array}{l}107.5 \pm 4.425 \\
a^{* * *}, b^{* *}, c^{* * *}\end{array}$ & $\begin{array}{l}67.5 \pm 4.233 \\
\mathrm{a} * * *, \mathrm{~b} * * *, \mathrm{c} * \\
*\end{array}$ & $\begin{array}{l}3.83 \pm 0.3073 \\
a^{* *}, b^{*}, c^{*}\end{array}$ \\
\hline
\end{tabular}

The data were analyzed by one way ANOVA followed by Tukey's multiple comparisons Test.

Each values represents the mean \pm SEM; $n=6,{ }^{*} p<0.05, * * p<0.01, * * * p<0.001$

a- Significant difference as compare to normal control group

b- Significant difference as compare to negative control group

c- Significant difference as compare to standard group

d- Significant difference as compare to ethanolic group 
Evaluation of hepatoprotective activity of abelmoschus moschatus seed in paracetamol induced...

Graph 1. Evaluation of effect of Abelmoschus moschatus on serum SGOT, SGPT, ALP, T.B in paracetamol+ ethanol induced hepatotoxicity.

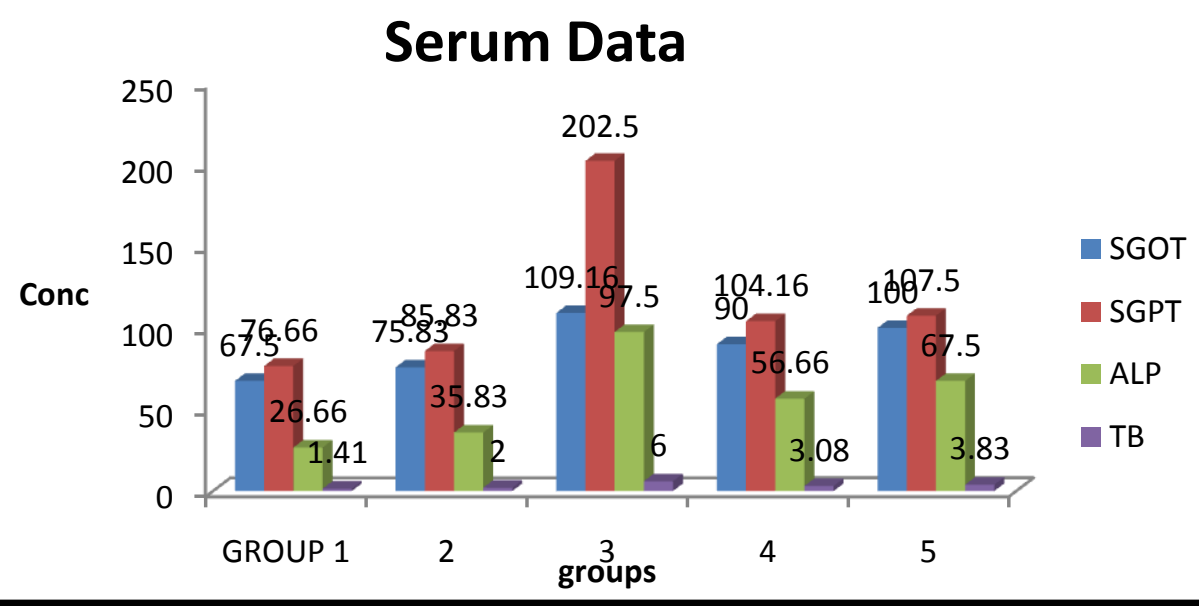

Table 6. Evaluation of effect of Abelmoschus moschatus on serum TG and TC, in paracetamol+ ethanol induced hepatotoxicity.

\begin{tabular}{|l|l|l|l|}
\hline S.N. & GROUP & TG $(\mathbf{m g} / \mathbf{d l})$ Mean \pm SEM & TC $(\mathbf{m g} / \mathbf{d l})$ Mean \pm SEM \\
\hline 1 & Normal control & $134.23 \pm 0.40$ & $102.14 \pm 0.46$ \\
\hline 2 & Standard & $\begin{array}{l}150.32 \pm 0.34 \\
\mathrm{a}^{* * *}, \mathrm{~b}^{* * *}\end{array}$ & $\begin{array}{l}136.22 \pm 0.21 \\
\mathrm{a}^{* * *}, \mathrm{~b}^{* * *}\end{array}$ \\
\hline 3 & Negative control & $\begin{array}{l}335.35 \pm 0.51 \\
\mathrm{a}^{* * *}\end{array}$ & $\begin{array}{l}220.41 \pm 0.20 \\
\mathrm{a}^{* * * *}\end{array}$ \\
\hline 4 & Test-2(Alcoholic) & $\begin{array}{l}201.34 \pm 0.50 \\
\mathrm{a}^{* * *}, \mathrm{~b}^{* * *}, \mathbf{c}^{* * *}, \mathrm{~d}^{* * * *}\end{array}$ & $\begin{array}{l}170.11 \pm 0.43 \\
\mathrm{a}^{* * *}, \mathrm{~b}^{* * *}, \mathbf{c}^{* * *} \mathrm{~d}^{* * * *}\end{array}$ \\
\hline 5 & Test-1(aqueous) & $\begin{array}{l}171.33 \pm 0.41 \\
\mathrm{a}^{* * *}, \mathrm{~b}^{* * *}, \mathbf{c}^{* * * *}\end{array}$ & $\begin{array}{l}167.34 \pm 0.32 \\
\mathrm{a}^{* * *}, \mathrm{~b}^{* * *}, \mathbf{c}^{* * *}\end{array}$ \\
\hline
\end{tabular}

The data were analyzed by one way ANOVA followed by Tukey multiple comparisons Test.

Each values represents the mean \pm SEM; $n=6,{ }^{*} \mathrm{p}<0.05, * * \mathrm{p}<0.01, * * * \mathrm{p}<0.001$

a- Significant difference as compare to normal control group

b- Significant difference as compare to negative control group

c- Significant difference as compare to standard group

d- Significant difference as compare to aqueous group

Graph 2. Evaluation of effect of Abelmoschus moschatus on serum TG and TB in paracetamol + ethanol induced hepatotoxicity.

\section{Cholesterol}

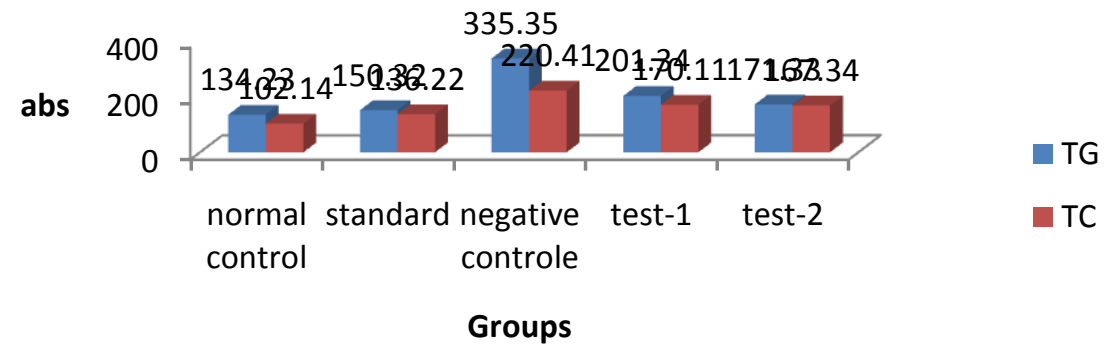


Evaluation of hepatoprotective activity of abelmoschus moschatus seed in paracetamol induced...

Table-7. Evaluation of effect of Abelmoschus moschatus on Blood Glucose in paracetamol+ ethanol induced hepatotoxicity.

\begin{tabular}{|l|l|l|}
\hline S. no. & Group & Blood Glucose $(\mathbf{m g} / \mathbf{d l})($ Mean \pm SEM) \\
\hline 1 & Normal control & $82.66 \pm .95$ \\
\hline 2 & Standard & $\begin{array}{l}91.83 \pm .83 \\
\mathrm{a}^{* * *}, \mathrm{~b}^{* * *}\end{array}$ \\
\hline 3 & Negative control & $\begin{array}{l}105.66 \pm .55 \\
\mathrm{a}^{* * *}\end{array}$ \\
\hline 4 & Test-2(alcoholic) & $\begin{array}{l}96.66 \pm .90 \\
\mathrm{a}^{* * *}, \mathrm{~b}^{* * *}, \mathrm{c} * * *\end{array}$ \\
\hline 5 & Test-1(aqueous) & $\begin{array}{l}98.66 \pm .71 \\
\mathrm{a}^{* * *}, \mathrm{~b}^{* * *}, \mathrm{c} * *\end{array}$ \\
\hline
\end{tabular}

The data were analyzed by one way ANOVA followed by Tukey multiple comparisons Test.

Each values represents the mean \pm SEM; $n=6, * p<0.05, * * p<0.01, * * * p<0.001$

a- Significant difference as compare to normal control group

b- Significant difference as compare to negative control group

c- Significant difference as compare to standard group

d- Significant difference as compare to aqueous group

Graph-3. Evaluation of effect of Abelmoschus moschatus on Blood Glucose in paracetamol+ ethanol induced hepatotoxicity

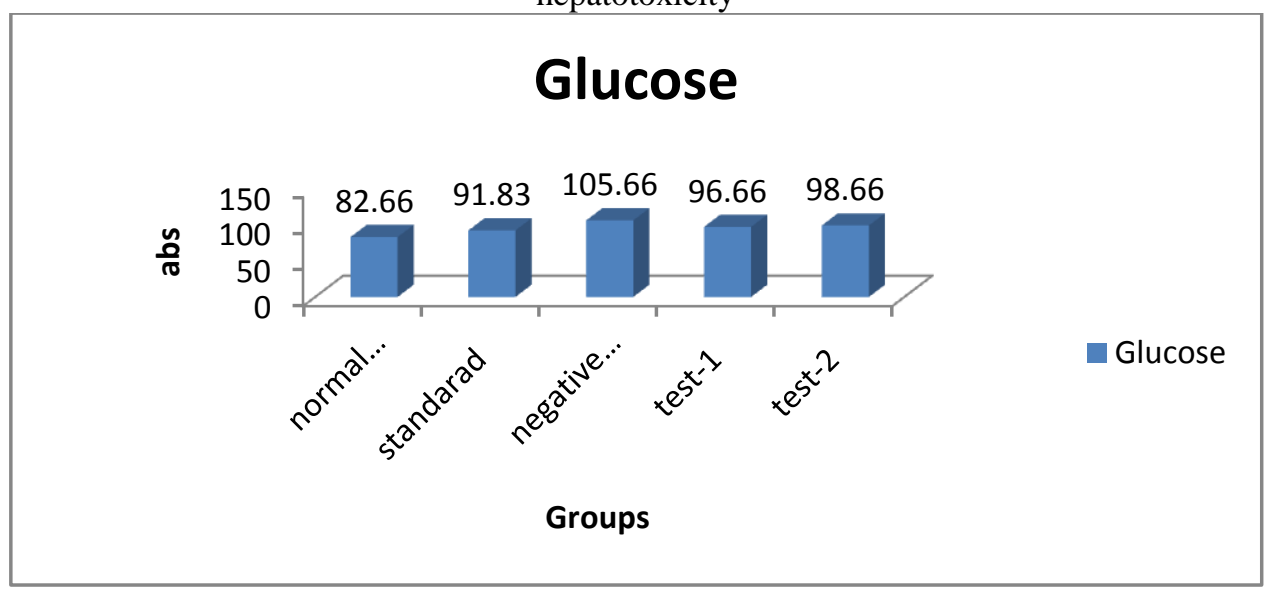

5. Histopathological study

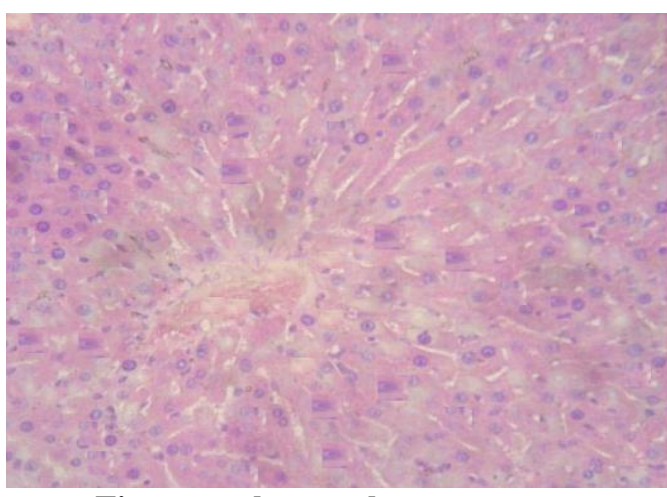

Fig-normal control

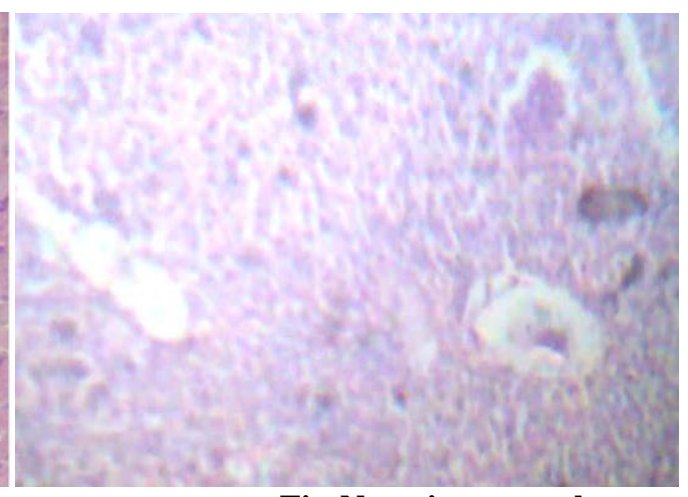

Fig-Negative control 


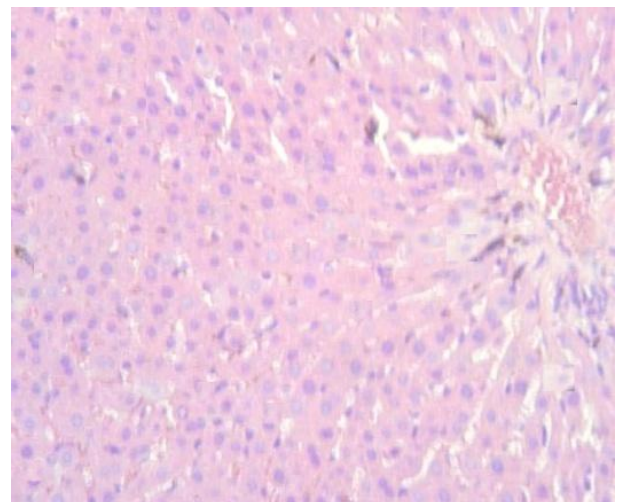

Fig-Standard

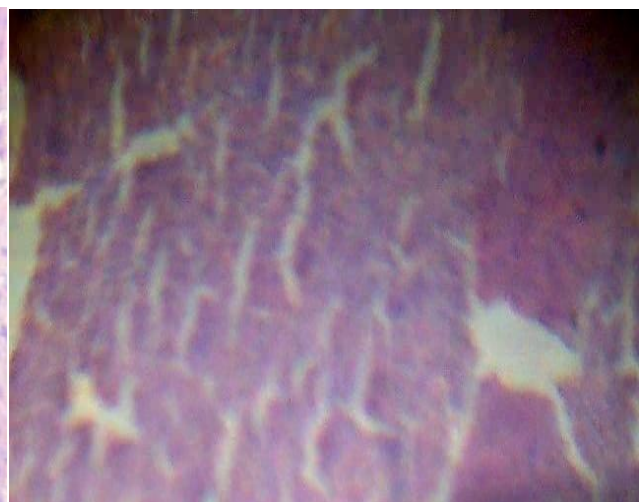

Fig-Aqueous extract

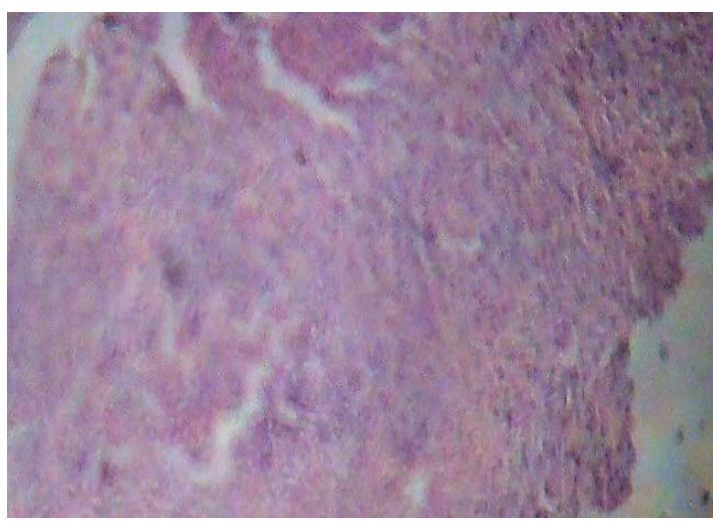

Fig- Alcohalic extract

\section{DISCUSSION}

The object of my project is to study the Hepatoprotective activity of Abelmoschus moschatus seed extract. Instead of presence of various types of allopathic drugs for Hepatoprotective, herbal drugs are preferred in the market due to its safety.

The Abelmoschus moschatus is cultivated in most places of India. It is usually shown in March-April. Seed are black in colour and irregular in shape and having bitter and acrid taste.

From the extraction of Abelmoschus moschatus seed alcoholic extract was found-2.4\% and aqueous extract was found-1.8\%. The alcoholic extract of seed contains Flavonoid, Total phenol compounds, Nitrogenous compound and Rasines while while aqueous extract contains only Flavonoid, Total phenol compounds, and Nitrogenous compound other compound such as Alkaloids, Saponine, Tannins, Glycosides are absent. The seed contains $11.14 \%$ moisture and $15 \%$ Ash value. (Table-6.1, 6.2)

The hepatoprotective activity is studied by the paracetamol + ethanol induced hepatotoxicity in either sex of Wister albino rats. The protocol was taken for 14 days and drugs were administered orally. The degree of liver damage is determined by investigation of various parameter i.e.-SGOT, SGPT, TB, and ALP, and other parameter which assist these study are Total Cholesterol, Triglycerides, and blood Glucose levels etc, and finally Histopathological studies. (Table-5.9.2)

Paracetamol is widely used as antipyretic and analgesic drugs, causes hepatotoxicity if taken in the excess amount of dose. The mechanism of hepatotoxicity is firstly cause the necrosis of Centilobular hepatocytes and followed by lipid per oxidative degradation of glutathione and produces cell necrosis in liver due to the formation of intermediate oxidative product of paracetamol ( $\mathrm{N}$-acetyl-P-benzoquinoneimine).(Kapur V. et al, 1994)

Most of the people consume Ethenol which causes the liver damage by the mechanism i.e.-alcohal consumption causes increased activity of TNF- $\alpha$ is the increased intestinal permeability due to liver disease.This facilitates the absorption of the gut-produced endotoxin into the portal circulation. The Kupffer cells of the liver then phagocytose endotoxin, stimulating the release of TNF- $\alpha$. TNF- $\alpha$ then triggers apoptotic pathways through the activation of caspases, resulting in cell death. (Menon KV, et al, 2001)

The extract contains Flavonoid, total phenol compounds and Nitrogenous compounds show the significance role in liver disease which was administered orally $300 \mathrm{mg} / \mathrm{kg}$ (according to OECD-423) to whister rat single times in a day. Silymarine $(25 \mathrm{mg} / \mathrm{kg})$ was selected as the standard drug which is well known Hepatoprotective drug. 
Significance was observed by evaluating the SGOT, SGPT, TB, and ALP, (appear lowering). Histopathology examinations of liver section support the study.

AST predominantly found in mitochondria of hepatocytes. ALT is more specific to liver, and thus is a better parameter for detecting liver injury. Serum ALP and bilirubin is also associated with liver cell damage. The ALT, AST and ALP activity and serum bilirubin level are largely used as most common biochemical markers to evaluate liver injury [Kozer E, et al, 2003].

Administration of paracetamol caused a significant elevation of enzymes level such as AST, ALT, ALP and bilirubin level has been attributed to the damage structural integrity of liver, because they are cytoplasmic in location and released into circulation after cellular damages indicating development of hepatotoxicity [Sallie R., et al, 1991]

In this experiment it was founded that Abelmoschus moschatus seed extract $300 \mathrm{mg} / \mathrm{kg}$ show the significant result in the paracetamol induced hepatotoxicity as the value of SGOT, SGPT, ALP and TB, were found significant $(\mathrm{p}<0.001)$ compared with paracetamol treated and less significant $(\mathrm{p}<0.1-0.05)$ when compared with only vehicle treated statically by one way ANOVA followed by Tukey's multiple comparison test.

\section{REFERENCES}

[1]. Agharkar, S.P. 1991. Medicinal plants of Bombay presidency. Scientific Publ. Jodhpur, India. First reprint, 1:p. 12

[2]. Aghela N, Rashidib I, Mombeinia A. 2007. Hepatoprotective Activity of Capparis spinosa Root Bark against $\mathrm{CCl}_{4}$ Induced Hepatic Damage in Mice. Iran J Pharma Res, 6 (4): 285-290.

[3]. Ahmad F, Khan RA, Rasheed S., 1994. Preliminary screening of methanolic extract of Celastrus paniculatus and Tecomella undulata for analgesic and anti-inflammatory activities. Journal of Ethnopharmacology, (42): 193-198.

[4]. Arcidi JM, Moore GW, Hutchins GM, 1981. "Hepatic morphology in cardiac dysfunction: a clinico pathologic study of 1000 subjects at autopsy". Am. J. Pathol. 104 (2): 159-66.

[5]. Barreira JCM, Ferreira ICFR, Oliveira MBPP, Pereira JA, 2008. : Antioxidant activities of the extracts from Chestnut flower, leaf, skins and fruit. Food Chem, 107:1106-1113.

[6]. Bastida G, Nos P, Aguas M, Beltrán B, Rubín A, Dasí F, Ponce J, 2005. "Incidence, risk factors and clinical course of thiopurine-induced liver injury in patients with inflammatory bowel disease". Aliment Pharmacol Ther 22 (9): 775-82.

[7]. Benjamin L. Shneider; Sherman, Philip M. 2008. Pediatric Gastrointestinal Disease. Connecticut: pmph-usa. 2: pp. 751.

[8]. Boyer JL, Klatskin G. 1970. "Pattern of necrosis in acute viral hepatitis. Prognostic value of bridging (subacute hepatic necrosis)". N. Engl. J. Med. 283 (20): 1063-71.

[9]. Cao J, Xu Y, Chen J, Klauning JE. 1996. Chemopreventive effects of green tea and black tea on pulmonary and hepatic carcinogenesis. Funda Appl Toxicol 29:244-250.

[10]. Cotran, Ramzi S.; Kumar, Vinay; Fausto, Nelson; Nelso Fausto; Robbins, Stanley L.; Abbas, Abul K. 2005. Robbins and Cotran pathologic basis of disease (7th Ed.). St. Louis, MO: Elsevier Saunders.45: p. 878.

[11]. Dixit N, Baboota S, Kohli K, et al., 2007. Silymarin: A review of pharmacological aspects and bioavailability enhancement approaches. Indian Journal of Pharmacology, 39: 172-179.

[12]. Donald Blumenthal; Laurence Brunton; Keith Parker; Lazo, John S.; Iain Buxton 2006. Goodman and Gilman's Pharmacological Basis of Therapeutics Digital Edition. McGraw-Hill Professional.

[13]. Friedman, Scott E.; Grendell, James H.; McQuaid, Kenneth R. 2003. Current diagnosis \& treatment in gastroenterology. New York: Lang Medical Books/McGraw-Hill. 40:pp. 664-679.

[14]. Gimson A. E. 1996. "Fulminant and late onset hepatic failure". Br J Anaesth 77 (1): 90-8.

[15]. Girish, C., Koner, B.C., Jayanthi, S., Rao, K.R., Rajesh, B. and Pradhan, S.C.: 2009, Indian J Med Res., 129(5): 569-578.

[16]. Gutiérrezl, R.M.P. and Solís, R.V. 2009: Rec. Nat. Prod., 3(1): 46-51.

[17]. I.-M. Liu, Thing-Fong Tzeng, Shorong-Shii Liou, 2010. Abelmoschus moschatus (Malvaceae), an aromatic plant, suitable for medical or food uses to improve insulin sensitivity, Phytotherapy Research: 24(2):233.

[18]. Jayasekar P, Mohanan PV, Rathinam K, 1997. Hepatoprotective activity of ethyl acetate extract of Acacia catechu. Indian Journal of Pharmacology, 29: 426-429.

[19]. Jessica R. Oesterheld; Kelly L. Cozza; Armstrong, Scott 2003. Concise Guide to Drug Interaction Principles for Medical Practice: Cytochrome P450s, Ugts, P-Glycoproteins. Washington, DC: American Psychiatric Association. 41(4):pp. 167-396.

[20]. Kapur V, Dillai KK, Husain SZ, Balani DK, Ind.J.Pharmacol.,1994;26(4),301-3.

[21]. Keppler D, Lesch NR, Reutter W, Decker K. 1968. Experimental hepatitis induced by Dgalactosamine.Exp Mol Path; 9:279-290.

[22]. Khatri A, Garg A, Agrawal SS, 2009. Evaluation of hepatoprotective activity of aerial part of Tephrosia purpuria L. and stem bark of Tecomella undulata. Journal of Ethnopharmacology, 122: 1-5.

[23]. Kim KH, Kim YH, Lee KR 2007. Isolation of quinic acid derivatives and flavonoids from the aerial parts of Lactuca indica L. and their hepatoprotective activity in vitro. Bioorg. Med. Chem. Lett. 17(24): 6739-6743.

[24]. Kinoshita S, Inoue Y, Nakama S, Ichiba T, Aniya Y 2007. Antioxidant and hepatoprotective actions of medicinal herb, Terminalia catappa L. from Okinawa Island and its tannin corilagin. Phytomed, 14(11): 755-762. 
[25]. Kirsch R, Yap J, Roberts EA, Cutz E 2009. "Clinicopathologic spectrum of massive and sub massive hepatic necrosis in infants and children". Hum. Pathol. 40(4): 516-26.

[26]. Kirtikar KR, Basu BD, 2001. Indian Medicinal Plants. Volume 8. Edited by Blatter E, Caius JE, Mhaskar KS. Dehradun: Oriental Enterprises, 23:2536-2537.

[27]. Kozer, E., Evans, S., Barr, J., Greenberg, R., Soriano I, Bulkowstein, M, Petrov, I., Chen-Levi, Z., Barzilay, B. and Berkovitch, M. 2003: Br J Clin Pharmacol., 55(3): 234-40.

[28]. Kokate C.K, Purohit A.P, Ghokale S.B, 2007. "Theory book of Pharmacognosy" 39:133-539.

[29]. Lee E R, Kang G H, Cho SG, 2007. Effect of flavonoids on human health: old subjects but new challenges. Recent Pat Biotechnol. ; 1(2):139-50.

[30]. Lim JR, Faught PR, Chalasani NP, Molleston JP 2006. "Severe liver injury after initiating therapy with atomoxetine in two children". J. Pediatr. 148 (6): 831-4.Lynch T, Price A 2007. "The effect of cytochrome P450 metabolism on drug response, interactions, and adverse effects". American Family Physician 76 (3):391-6.

[31]. Menon KV, Gores GJ, Shah VH 2001. "Pathogenesis, diagnosis, and treatment of alcoholic liver disease" 76 (10):1021-9.

[32]. Michalets EL 1998. "Update: clinically significant cytochrome P-450 drug interactions".Pharmacotherapy 18 (1): 84-112.

[33]. Morikawa T, Matsuda H, Ninomiya K, Yoshikawa M. 2007. New flavanone oligo glycosides, thea flavanosides I, II, III, and IV, from the seeds of tea plant (Camellia sinensis) shows hepatoprotective activity. Heterocycles, 71(5): 1193-1201.

[34]. Nadir A, Reddy D, Van, et al, 2000. "Cascara sagrada-induced intrahepatic cholestasis causing portal hypertension: case report and review of herbal hepatotoxicity". Am. J. Gastroenterol. 95 (12): 3634-7

[35]. Nakanuma Y, Sasaki M, Terada T, Harada K, 1994. "Intrahepatic peribiliary glands of humans. II. Pathological spectrum". J. Gastroenterol. Hepatol. 9 (1): 80-6.

[36]. Orhan DD, Orhan N, Ergun E, and Ergun F, 2007. Hepatoprotective effect of Vitis vinifera L. leaves on carbon tetrachloride induced acute liver damage in rats. J Ethnopharmacol; 112 (1): 145-151.

[37]. Ostapowicz G, Fontana RJ, Schiødt FV, et al, 2002. "Results of a prospective study of acute liver failure at 17 tertiary care centres in the United States". Ann. Intern. Med. 137 (12): 947-54.

[38]. Rastogi, R.P. and B.N. Mehrotra, 1991. Compendium of Indian Medicinal Plants. Vol. I: 1960-1969.

[39]. Reitman S, Frankel S, 1957. A colorimetric method for determination of serum glutamate oxaloacetate and glutamic pyruvate transaminase. American Journal of Clinical Pathology, 28: 56-58.

[40]. Sadeghi H, Nikbakht M, Ghaitasi I, Sabzali S. 2008. Hepatoprotective effect of Cichorium intybus on $\mathrm{CCl}_{4^{-}}$ induced liver damage in rats. Afr J Biochem Res; 2 (6): 141- 144.

[41]. Sallie, R., Tredger, J.M. and William, R. 1991: Biopharm Drug Disp., 12: 251-259.

[42]. Selves J, Kamar N, Mansuy JM, Péron JM, 2010. "Hepatitis E virus: A new entity" Ann Pathol 30(6): 432-8.

[43]. Shukla S, Bhadauria M, Sharma A, et al., 2005. Hepatoprotective effect of a propriety herbal formulation on experimental liver damage in rats. Toxicology International, 12: 75-81.

[44]. Somchit MN. Sulaiman MR. Noratunlina R, Ahmad Z. 2002. Hepatoprotective effects of Curcuma longa rhizomes in paracetamol induced liver damage in rats. Proceedings of the Regional Symposium on Environment and Natural Resources Kuala Lumpur, Malaysia. 1: 698-702.

[45]. Vetrivel R, Shanmugavalli N, Greety S, Umashankar V. 2009. Hepatoprotective effects of Cassia tora on $\mathrm{CCl}_{4}$ induced liver damage in albino rats. Ind J Sci Tech; 2 (3):41-44.

[46]. Wanless IR 1995. "Terminology of nodular Hepatocellular lesions". Hepatology 22 (3): 983-993.

[47]. Yang J, Paulino R, Janke-Stedronsky S, Abawi F: 2007. Free radical scavenging activity and total phenols of noni (Morinda citrifolia L.) juice and powder in processing and storage. Food Chem., 102:302-308. 